Command coordination and tactical effectiveness in counterinsurgency operations: lessons from the South Korean campaign

Soul Park ${ }^{\mathrm{a} *}$ and Seung Joon Paik ${ }^{\mathrm{b}}$

${ }^{a}$ Department of Political Science, National University of Singapore, Singapore;

${ }^{b}$ Department of Political Science, George Washington University, Washington DC, USA

CONTACT *corresponding author: Soul Park (polsp@nus.edu) 


\section{Command coordination and tactical effectiveness in counter- insurgency operations: lessons from the South Korean campaign}

This article systematically analyzes the causes of combat effectiveness of the South Korean security forces through the course of its various counter-insurgency (COIN) operations from 1948 to 1953. We argue that improvements in two interrelated aspects ultimately resulted in higher level of performance at the operational and tactical level: unified operational command structure and the subsequent improvements in tactical efficiency under the guidance of the US advisory mission. We analyze the key factors that influenced the overall performance of the South Korea's COIN operations by examining four incidents/crises that occurred from 1948 to 1953: the Jeju Island Uprising, YeoSoon Rebellion, Chiri Mountain operations (1948-1950), and Operation RATKILLER. Through an in-depth case study on how a nascent army improved its capacity in combating homegrown insurgencies, we demonstrate how the actual conduct of operations itself remains just as significant in the assessment of overall COIN outcomes.

Keywords: counterinsurgency (COIN), interagency cooperation and coordination, indigenous forces, Korean Constabulary (KC), Republic of Korea Army (ROKA), Korean National Police (KNP), tactical effectiveness

\section{Introduction}

In the immediate aftermath of World War II, Korea's path to liberation from Japanese occupation was mired with persistent internal security threats and challenges from various political elements. ${ }^{1}$ Countering these internal threats was indispensable to statebuilding initially for the American Military Government (AMG) and later the newly established Republic of Korea (ROK) government. The Korean Constabulary (KC) and the nascent ROK Army (ROKA) afterwards painstakingly conducted counterinsurgency (COIN) operations and had all but eliminated communist guerrillas from the southern 
zone of the Korean peninsula by $1956 .{ }^{2}$ Overall, it can largely be argued that the Korean COIN campaign conducted during this period had achieved all of its overarching goals.

One notable aspect of the South Korean COIN experience is the marked improvement of the KC/ROKA performance level throughout the various operations. The missions conducted on Jeju Island eventuated in disastrous outcomes despite the wide gap in physical capabilities between the insurgents and government forces. On the island itself, 2,622 KC troops, 1,700 Korean National Police (KNP) officers, and 50,000 civil defense personnel were barely able to suppress the isolated local guerrilla group of roughly 600 members who were armed with only 240 Japanese 99-type rifles. In contrast, the ROKA units were able to perform at a much higher tactical and operational standard in its later operations. While fighting conventional battles against the North Korean and Chinese forces at the front line, the ROKA effectively suppressed approximately 10,000 guerrillas in the southern zone, many of whom were wellequipped and trained North Korean soldiers.

This paper systematically analyzes the key factors that influenced the overall performance of the South Korea's COIN operations from 1948 to 1953. More specifically, we trace the causes of combat effectiveness of the Korean security forces through the course of its various operations. ${ }^{3} \mathrm{We}$ argue that improvements in two interrelated aspects ultimately resulted in higher level performance at the operational and tactical level: the unity of operational command structure and the subsequent improvements in tactical efficiency achieved through the guidance and oversight of the US advisory mission. ${ }^{4}$ First, the unification of the command structure minimized interference from the political leaders and paved the way for better cooperation and coordination amongst various government security forces. Furthermore, a much more simplified and a cohesive command climate also permitted the most competent junior- 
level officers for the mission to be selected, and they would go on to make a marked difference on the field. Second, tactical effectiveness also underwent marked improvements during the course of the COIN campaign. Not only was this partly due to the implementation of a simplified command but also because of the continuous efforts put in by US advisors on the ground; continuous oversight of missions were recorded and joint intelligence efforts to weed out troops with dubious loyalties were conducted. Subsequently, operationally-proven officers were given the initiative to display adaptability to both the environment and the enemy that they faced.

More broadly, our research contributes to the existing COIN literature in a number of interrelated ways. First, our work builds upon recent work on the issue of combat effectiveness in COIN operations, which remains an understudied theme within the literature. ${ }^{5}$ Second, we examine the causes of combat effectiveness of an indigenous force (or non-great power). The South Korean case remains one of the earliest and arguably one of the most successful cases of US efforts to develop an indigenous security force after World War II. ${ }^{6}$ As such, we focus on the COIN aspect of the advisory mission in particular to highlight the development of an independent Korean security force. Lastly, our study aims to contribute further to the growing literature on the role of indigenous security forces in COIN operations. ${ }^{7}$

This paper is organized as follows. The next section briefly describes the hectic period surrounding the creation and development of the Korean security force in the aftermath of the World War II. In the process we outline some of the issues and challenges that the US forces and the nascent Korean government faced in forming a separate security force to combat internal threats. The next section examines four cases that occurred between 1948 and 1953: the Jeju Island Uprising, Yeosu-Soonchun (YeoSoon) Rebellion/Mutiny, Chiri Mountain Operations, and Operation RATKILLER. The 
cases, presented chronologically, all address the issues of combat effectiveness at the operational and tactical level. That is, it is through within-case analysis based on primary sources (such as interviews/memoirs, committee reports and archival record) that we capture the changes brought about by a unified command structure and US advisory effort specifically for COIN operations. ${ }^{8}$ Lastly, we discuss our findings from the four cases before concluding with broader implications for future COIN research.

\section{Creation of the Korean constabulary: early development and obstacles}

As World War II dawned to a close, the US armed forces moved quickly into the southern zone of the Korean peninsula, both to organize the withdrawal of the surrendering Japanese forces and to act as a balancing force against Soviet forces stationed in the northern zone. ${ }^{9}$ Upon arrival, the US Armed Forces in Korea (USAFIK) quickly recognized the need to create and set about implementing an effective indigenous South Korean security force. The South Korean constabulary was initially established on 14 January, 1946. Nevertheless, the US advisory mission and experience prior to World War II, in general, was limited and the AMG mostly conducted a 'trialand-error' strategy: 'the defense force was an adaptation to circumstances, a spontaneous creation of the US occupation forces to meet an immediate need. ${ }^{10}$ No clear policy or doctrine on how to develop a ROK security force existed.

Envisioned as the foundation of a future ROK Army, the KC was initially designed to function as an auxiliary force structure to the KNP in dealing with internal security issues. ${ }^{11}$ Moreover, its organization was territorial in nature: 'one company would be formed in each of the eight provinces of South Korea', and 'each provincial regiment was responsible for recruiting its own constabulary-men. ${ }^{12}$ That is, the formation and recruitment of constabulary units would be done independently in each province. 
Responsibility for training the $\mathrm{KC}$ was initially assigned to the USAFIK. ${ }^{13}$ However, after the election of Syngman Rhee as the first president of the Republic of Korea, the undermanned and underfunded Provincial Military Advisory Group (PMAG) was burdened with the task of training government forces. ${ }^{14}$ As the US prepared to pullout completely from the Korean peninsula in 1949, the United States Military Advisory Group to the Republic of Korea (KMAG) was created in place of PMAG, in order to continue with the training of the ROK Army. ${ }^{15}$ Under the guidance of both PMAG and KMAG, the constabulary continued to develop and ended up playing a critical role in the peninsula-wide COIN operations that took center stage from 1948 onwards.

Efforts both to develop and train a separate ROK security force were confronted by three interrelated challenges in the early stages. First, officer training capacity initially could not keep pace with the actual growth of the constabulary. Such imbalance between the growth of actual units and officer corps resulted in the premature promotion of inexperienced and, often times, incompetent junior-level officers. ${ }^{16}$ Moreover, a lack of knowledge of the Korean culture and language barriers led to the recruitment of a large number of officers with dubious loyalties towards the newly formed South Korean state or with strong leftist views. ${ }^{17}$ Without a strict set of criteria and requirements for an effective security force, competent and experienced leadership at levels was lacking. The officer corps, in particular, was inexperienced, incompetent, and politically divided.

Second, the constabulary was essentially created 'under fire' due to continuous attacks by insurgent groups. Combined with a lack of equipment this hampered its initial operations and growth. ${ }^{18}$ Finally, the $\mathrm{KC}$ was organized and trained to deal with internal security issues as an auxiliary force to the KNP, but not under the command of the latter. As the constabulary forces grew in both size and prestige and without clearly 
delineated roles under the AMG, rifts between the two security branches would appear and become increasingly severe. ${ }^{19}$ Further fueling this rivalry between the $\mathrm{KC}$ and the KNP was an ideological divide, as the latter was composed primarily of right-leaning personnel.

In a nutshell, efforts to develop an indigenous South Korean security force, particularly one that could deal with internal threats, were mired in complex political and social challenges. American advisors mostly lacked a clear-cut policy and doctrine and the trial-and-error approach that they had adopted in essence remained inadequate in tackling concerns surrounding the composition and effectiveness of the fighting force. Consequently, the $\mathrm{KC}$ units were mostly inexperienced and politically divided and its leadership for the most part incompetent. It is within this context that the government forces embarked on COIN missions that would last from more than six years.

\section{Jeju Island uprising: brutality and tactical ineffectiveness}

A mass demonstration on Jeju Island commemorating the $1^{\text {st }}$ March Korean independence movement from Japanese colonial rule resulted in skirmishes between demonstrators and members of the KNP sent to maintain public order. In the processes, government troops opened fire on the demonstrators, killing six. These killings set the stage for a year of growing unrest on the island and increasing tensions between the islanders, on the one hand, and the KNP, on the other. ${ }^{20}$ Tensions soon boiled over, ultimately leading to the eruption of a full-blown insurgency in early April 1948, when insurgents launched a coordinated attack on 12 police stations. While government forces eventually managed to defeat the insurgency, their COIN campaign was marked a lack of interagency cooperation and co-ordination between the $\mathrm{KC}$ and $\mathrm{KNP}$, and 
overall tactical ineptness. In fact, it was because of these three factors, it appears, that the insurgency lasted as long as it did. ${ }^{21}$

Violent repression to suppress the outbreak of the insurgency was the immediate response selected by the central government in April 1948. Making little effort to identify and resolve local grievances that were at the root of the insurgency, the nascent government of Rhee sent reinforcements to the island with orders to put down the rebellion by force. ${ }^{22}$ In early May 1948, Lt. Col. Jin-kyung Park of the $11^{\text {th }}$ Regiment was appointed as commanding officer of the newly installed Jeju Island Constabulary Command. ${ }^{23}$ Lt. Col. Park initiated a three-phase COIN strategy: 1) construction of strategic hamlets to separate the population from the insurgents and which were to be guarded by local police and militias; 2) sweeping operations around the Halla Mountain region by $11^{\text {th }}$ Regiment to identify and destroy insurgent units; and 3) the creation of screening centers to identify and eliminate suspected leftists. ${ }^{24}$ Lt. Col. Park's regiment adopted an aggressive approach to suppress the insurgency. Mass arrests and prosecution followed as an estimated 3,000-4,000 were hauled into detention centers. ${ }^{25}$

After an initial wave of repression, which seemed to have subdued the insurgency, fighting flared up again in August of 1948. This, in turn, led to a renewal and escalation of the COIN campaign. After some setbacks, the constabulary forces regrouped and regained the momentum by November of that year. In doing so they significantly increased the level of repression. The COIN campaign reached a much bloodier stage leading to the massacre of thousands of civilians. More than 80 percent of the villages situated in the middle of the island were pillaged during this period of renewed violence, despite the fact that the insurgent forces never amounted to more than roughly 600 combatants at any given moment. ${ }^{26}$ As John Merrill notes, '[t]he violence reached its peak in mid-December when 630 persons were killed in a single 
week. The disproportion between guerrilla and constabulary losses, as well as the limited number of weapons captured, indicate that the government forces resorted to a tremendous amount of overkill. ${ }^{, 27}$ Not only this, government forces also relocated about 100,000 civilians, while 'destroying nearly 40,000 homes.' 28

The repression continued throughout 1949. In March of that year, a special combat command, led by Col. Chae-hung Yoo, was put in charge of mop-up operations on the island and was given specific orders to 'clean up the estimated 500 remaining guerrillas by April [1949]. ${ }^{29}$ Reinforcements were still being sent from the mainland to the island. In addition to the $2^{\text {nd }}$ Regiment and auxiliary units, the special combat command was reinforced with a paramilitary force, a 'separate ranger battalion, railroad police detachments, and elements from the South Chungchong Province police'. ${ }^{30}$

The special combat command continued the strategy of brutality adopted by its predecessors. In its first month, the operation killed a purported 2,345 insurgents and 1,668 civilians. ${ }^{31}$ Likewise, in March, the US G-2 periodic report pointed out that "an estimated 14,000-15,000 civilians had been killed with at least 80 percent of the casualty a result of the government forces." ${ }^{32}$ By December 1949 the COIN campaign had achieved its desired effects, although at great cost to the civilian population. The insurgency was on the wane. A last ditch insurgent offensive was defeated by the government forces, again with a great deal of brutality. The $\mathrm{KC}$, moreover, committed frequent atrocities against civilians. ${ }^{33}$ By the time that North Korea invaded the South in June 1950, the Jeju Island insurgency was over. In all, by relying on the widespread use of brutality and violence, the KC and the KNP had eliminated the insurgents. Pacification or civil operations as peaceful solutions to the insurgency, such as negotiation with the insurgent leadership and the release of captured non-combatant insurgents, were used by the KC during the initial (April-May 1948) and the final staged 
of the operation (March-May 1949), but such efforts were largely overshadowed by mass killings and forced relocation. ${ }^{34}$

Although the COIN campaign achieved its goal, the campaign also revealed significant weaknesses in the operational and tactical capabilities of the ROK security forces. In particular, the COIN campaign was characterized by interagency rivalries and tactical ineptness that would have made it difficult for the ROK security forces to emerge victorious from a conflict against a better organized insurgent movement. First, cooperation between the KNP, which spearheaded the Jeju COIN campaign, and the KC playing a support role was initially very poor. From their inceptions, the two organizations had experienced serious tension, which sometimes caused gang-fights, due to ideological differences: while the KNP leaned toward the right, the members of $\mathrm{KC}$ were relatively leftist in orientation. ${ }^{35}$ Such interagency rift between the two security branches would continue until the formation of the Jeju Island Constabulary Command. In one instance, the police would set a whole village situated in the middle of the island on fire and claim that it was the conduct of guerrillas merely to coerce constabulary participation. ${ }^{36}$ This was partly due to the fact that they did not share a single chain of command. Due to the lack of tactical coordination between the security units, even basic screening operations and search missions in and around the cities were often difficult to conduct. The constabulary would support the police with cordoning duties when necessary. But they would not be involved in any engagements or active missions, and the police on its own lacked the necessary manpower to achieve successfully their mission. ${ }^{37}$

Tensions between the KNP and $\mathrm{KC}$ were not only due to organizational issues, however. Many of the constabulary troops were islanders who sympathized with the insurgents. ${ }^{38}$ As the later focused their wrath primarily on the KNP and the right-wing 
youth group members, the constabulary was not inclined to get in the middle of the conflict. For many within the ranks, 'the rebellion was really a quarrel between the people and police. ${ }^{39}$ Such attitudes did not create a great deal of goodwill between the $\mathrm{KNP}$ and $\mathrm{KC}$ forces, as the former believed that the constabulary on the island was penetrated and infiltrated by communist elements.

Such interagency coordination and cooperation issues were noted by US advisers and attempts to rectify the situation were attempted throughout the campaign, especially in the early going. During the early phase of the uprising, the AMG sent Lt. Col. John Mansfield and Captain Clarence DeReus to help with coordination issues of the Jeju COIN operations, and in the process set-up the centralized Jeju Island Constabulary Command. ${ }^{40}$ In addition, the US advisors attempted to unify the command on the island by initiating an internal screening process to weed out the subversive elements within the constabulary ranks. Subsequently, a new Department of Internal Security G-2 unit was created. ${ }^{41}$ Finally, Col. Rothwell Brown of the US $6^{\text {th }}$ Regiment stationed in Kwangju was sent as a special adviser to the Jeju Island COIN operations. Col. Brown pointed to the near non-existent cooperation between different security forces as the main reasons behind the failure to suppress the insurgency at the start. ${ }^{42}$ Despite increased coordination of different security units at the tactical level, constabulary troops from the Jeju Island continued to be largely excluded from the COIN operations.

A second characteristic of the COIN campaign on Jeju was the tactical ineptness of the constabulary forces. Poor leadership and training were among the chief causes. Korean officers, moreover, failed to follow the advice from their US counterparts, and 'many of the army casualties can be attributed to the failure to follow the tactical suggestions of US advisors. ${ }^{43}$ Evidence also demonstrates the ineffective employment 
of forces during the campaign as certain $\mathrm{KC}$ elements were stationed in the peaceful areas at the edge of the island until the very end of operations rather than the mountainous area where active insurgency was ongoing. Such deployment of forces, as one leader of the $\mathrm{KC}$ admitted, more likely led to greater civilian abuses and uneconomic use of troops. ${ }^{44}$ It appears that the KC and KNP did achieve their victory only through superior fire-power and repressive means.

The Jeju Island uprising was not the only internal challenge facing the Rhee government in the years immediately prior to the outbreak of the Korean War. In October 1948, the violence on Jeju spilled over to the mainland. Although the rebellion that broke out around the cities of Yeosu and Soonchun in South Jeolla province had local roots, it provided the impetus for the outbreak of region-wide insurgency in the south, eventually led by the South Korean Labor Party (SKLP). ${ }^{45}$

\section{Yeo-Soon rebellion}

The heightening of armed struggle on Jeju Island was soon followed by the Yeo-Soon rebellion. On the evening of 19 October 1948 , a battalion of the $14^{\text {th }}$ Regiment, $5^{\text {th }}$ Brigade of the ROKA ${ }^{46}$ stationed just outside of Yeosu was ordered to reinforce the units fighting on Jeju Island. ${ }^{47}$ The regiment was well-armed having been recently supplied with American rifles and ammunition stocks. ${ }^{48}$ The regiment, however, was also infiltrated by leftist elements. These bad elements, estimated initially to be about 40 men, mutinied, killing and imprisoning 20 loyalist officers and rallying roughly 800 to their cause. ${ }^{49}$ Other SKLP sympathizers in the regiment joined the mutiny and the rebel force rapidly grew to approximately $2,000-3,000$ troops. $^{50}$

The rebels immediately engaged in a concentrated attack on KNP forces, rightist youth groups, and government sympathizers, as they took over Yeosu. In the process, they killed an estimated 500 people. ${ }^{51}$ The next morning, about a sixth of the insurgent 
force marched to the nearby city of Soonchun where two other companies of the $14^{\text {th }}$ Regiment linked up with the insurgent forces. ${ }^{52}$ By the afternoon of 21 October the insurgents were able to take hold of nearby small towns such as Kwangyang and Namwon, building a hastily formed defense line. ${ }^{53}$ Once the insurgents were in power, the Soonchun People's Committee and courts were resurrected, leading to the arrests and the mass execution of rightist leaders and youth group members in the area.

The Rhee administration, in consultation with American military advisers, quickly created a Counter-rebel Combat Command located in Kwangju under the leadership of then ROKA Commander-in-Chief, Brigadier General Ho-Sung Song. ${ }^{54}$ The $4^{\text {th }}$ Regiment from Kwangju was set to move east, elements from the $3^{\text {rd }}$ and $2^{\text {nd }}$ Regiment were to coordinate together as they went south from Chungchong Province, and units from the $5^{\text {th }}$ and $15^{\text {th }}$ Regiments were deployed both as holding positions to block insurgents from escaping towards the mountains. By the evening of 21 October, Yeosu was completely encircled and specially designated units for the operation under Lt. Col. Kim made their move from the north. ${ }^{55}$

The main priority of the newly created command was to retake the two cities, an effort that required substantial co-ordination and cooperation between units from eleven different brigades and regiments, including ROKA battalions from nearby regions such as Pusan, Taegu, and Kunsan. ${ }^{56}$ Eleven ROKA battalions, KNP combat units and rightwing youth groups were mobilized for the COIN operation. US assistance consisted of the provision of spotter planes and naval patrols to prevent possible North Korean and/or Soviet assistance and reinforcements for the insurgents. ${ }^{57}$ The strategy selected was simple. It consisted of a campaign designed to drive the strongest forces south starting from Soonchun. ${ }^{58}$ 
The fight to retake Soonchun did not last long as elements of the $4^{\text {th }}$ Regiment fought insurgent forces to a standstill around the Hakgu-ri area. Two battalions of the $12^{\text {th }}$ Regiment pushed through the insurgent lines, manned by around a thousand rebels and leftist youth group members. Once the rebels retreated, Maj. In-Yup Paik sent mobile units and targeted downtown police stations without delay in the hopes of destroying potential rebel strongholds. Although rebel resistance was weak, the ROKA forces retreated for reinforcements. The next morning, the ROKA units once more charged into Soonchun, with armored vehicles leading the main assaults. ${ }^{59}$ With the rebels in full retreat, however, the ROKA forces quickly turned their attention to rounding up potential rebel supporters and leftist leaders, allowing the insurgent forces to retreat either to the mountains or back to Yeosu.

By the evening the ROKA forces had regrouped and refocused, and managed to encircle Yeosu and nearby cities. Armored units pushed down from Soonchun while two battalions moved towards Polgyo-ri in an attempt to link up with the main units from Kwangju. ${ }^{60}$ The initial efforts to retake Yeosu experienced significant setbacks. Units from the $3^{\text {rd }}$ Regiment were hit by an insurgent ambush around Janggoon-bong, the main path leading to Yeosu. The ROKA units immediately retreated back and waited for reinforcement. On 26 October, the $12^{\text {th }}$ Regiment was sent from Kwangyang and once again placed as the main assault unit. By sending elements of this unit to Yeosu, the pacification of Kwangyang was not fully accomplished and once again allowed a huge number of insurgents to escape to Chiri and Paegun mountains. ${ }^{61}$ Even with the main insurgent forces escaping the city, strong resistance persisted and the ROKA had to rely on heavy firepower. Remaining forces put up a well-fortified defense, displayed accurate marksmanship and fought as well-organized units which often delayed advancing ROKA forces by setting fires all around the city. On 25 
October, ROKA forces relied on mortar fire and indiscriminate firing to pierce their way and later that day constabulary engaged in fierce, though limited, battles within the city. ${ }^{62}$ By early evening of the 27 October, the government forces had full control of Yeosu. Yet, most of the main insurgent units had already made their way into the Chiri mountain regions. ${ }^{63}$

Altogether, the initial response to the Yeo-Soon uprising achieved mixed results. Although the government forces succeeded in retaking the cities occupied by the insurgents, they did not succeed in defeating the majority of the insurgents who had escaped to fight another day. More importantly, ROKA forces suffered significant setbacks and overall did not perform very well despite their superior technological and manpower advantage. Two broad reasons could be found for the shortcomings and for the operational mistakes made.

First, the leadership structure in the Counter-rebel Command had not been firmly established until this point. During the initial stage of the COIN operations, there were changes in command authorities among top ROKA leaders. Brigadier General Song, the Commander-in-Chief of the ROKA, was the senior commander of the COIN operations. However, the brigades and regiments under Gen. Song were not actually commanded by him. Even though Gen. Song was willing to lead the COIN forces himself, he was excluded from the operations by other members of his staff. ${ }^{64}$ The aforementioned Cols. Kim and Paik, the Commander of the $5^{\text {th }}$ Brigade and the chiefof-staff of the Command respectively, with the guidance of Capt. James Hausman, a key figure in the American military advisory mission in South Korea and a military advisor to Gen. Song during the rebellion, led the troops. After initial defeat of the COIN forces at Soonchun on 20 October, for instance, Gen. Song maintained that the siege of the city should be resumed after concentrating troops, but Cols. Kim and Paik 
resumed the attack on the very next day, contrary to the commander's initial plan. ${ }^{65}$ Likewise, Col. Yong-dok Won, the commander of the $2^{\text {nd }}$ Brigade, was excluded from the leadership for the COIN operations. These leadership changes reflected the rise of the officers who had served in the Manchukuo Imperial Army (MIA), especially those who had gained military experience during COIN operations against anti-Japanese guerrillas during World War II. Even though the Brigade General Song was appointed as the commander-in-chief of the ROKA to emphasize the connection between the Korean Liberation Army (KLA) and the ROKA,${ }^{66}$ former MIA officers were considered better trained and more professional in an actual combat than those who served in the KLA. For example, Capt. Hausman was skeptical about the competence of former KLA officers, regarding the KLA as 'a mere accessory of Chiang Kai-Shek. ${ }^{\text {,67 }}$ Additionally, these rising junior officers' hawkish perspective on communism also played a role in their promotion. This reflects the growing anti-communist sentiment within ROKA ${ }^{68}$ However, the co-ordination problem between the police and army, which undermined the effectiveness of the COIN operations in Jeju, was significantly resolved during operations during the Yeo-Soon Incident. Under martial law was instituted, which became effective August 26, 1948, ${ }^{69}$ the ROKA maintained the strategic initiative, and the KNP took an auxiliary role in support of the ROKA. ${ }^{70}$

Moreover, the Rhee government intervened in the campaign and demanded that the government forces focus their attention on retaking the cities. Instead of being allowed to focus on destroying the enemy, government forces were obligated to concentrate their attention on the two cities rather than the rebel forces. The government did not offer the military sufficient time to prepare itself for offensive actions. As Alan Millett states, 'retaking a city was far more important than conducting a coordinated and careful campaign that would seal the Yeosu peninsula and capture the rebels. ${ }^{, 71}$ 
Second, the Korean government forces failed to display a great deal of tactical and operational competence, especially in terms of leadership. In fact, American advisers who were closely involved in the campaign were dismayed at the low level of soldiering exhibited by the Korean forces. Thus, both '[Col. Minor] Kelso and [Lt. Foster] Cowey were disgusted with the sloppy tactics, poor preparation, lethargy, and overall sense of apathy. ${ }^{72}$ As a result of the two factors, the operation to retake YeosuSoonchun was plagued by cooperation and co-ordination issues among the active units. Subsequently, overseeing the mission from headquarters was much more difficult than first envisioned by Capt. James Hausman and Lt. Col. Sun-Yup Paik. ${ }^{73}$ Units such as the task force of the $5^{\text {th }}$ Regiment failed to heed instructions by US advisors to cooperate with Col. Kim and tried to force their way through the ports of Yeosu, resulting in exposure to enemy heavy fire while accruing limited gains ${ }^{74}$ Likewise, battles that involved the elements of the $4^{\text {th }}, 6^{\text {th }}, 15^{\text {th }}$ and $12^{\text {th }}$ Regiments were mired in similar co-ordination problems. ${ }^{75}$ The campaigns were the first major combat operations undertaken by the ROKA since its creation. They did a great deal to expose the interrelated weaknesses of the organization: failures in leadership and poor coordination amongst the various units that ultimately resulted in substandard tactical performance. ${ }^{76}$ Altogether, therefore, the constabulary performed rather poorly.

The first phase of the COIN operations was immediately followed by the second phase: the pursuit of remaining insurgents and the purging of constabulary forces of leftists. Led by Col. Paik, the military intelligence agents brought in approximately 2,000-5,000 officers for trial, out of which more than 500 received death sentences. ${ }^{77}$ The purge, according to a KMAG adviser, improved the effectiveness of the ROK Army while at the same time settling a serious internal ideological divide: ' $[\mathrm{t}] \mathrm{he}$ Constabulary took on a new air of professionalism, confidence, and cooperation. ${ }^{78}$ 
As the constabulary purge was underway, special task force teams led by Colonels Won and Il-kwon Chong patrolled the mountain regions searching for remaining insurgent forces. General cordon-and-search operations were undertaken to search villages for possible guerrilla supporters. ${ }^{79}$ Gripped in ideological struggles, hatred-filled mass killing took over in an anarchical setting during next eight days of fighting. ${ }^{80}$

\section{Border conflicts and continuing COIN campaigns, 1948-1950}

Immediately following the Yeo-Soon battles, the Chiri Mountain (Chiri-san) COIN campaigns followed in pursuit of insurgent forces that escaped from the two cities. Until the eve of the Korean War some 19 months later, the South would be embroiled in widespread guerrilla activities, thus starting what is widely considered the second phase of mainland COIN operations and the initiation of organized guerrilla warfare in the southern zone. ${ }^{81}$ Due to continuing purges of officers and certain constabulary units, rebellions and mutinies of smaller scale persisted throughout the peninsula, such as the Taegu rebellion. The constabulary forces would go on to conduct more than 500 counter-guerrilla actions in the second half of 1949 alone. ${ }^{82}$

The second COIN (or spring suppression) campaign started in spring 1949 as guerrilla activities peaked along with rising border conflicts and North Korean infiltration into the South. ${ }^{83}$ Together with the North Korean agents, constabulary rebels, SKLP members and leftist youth initiated guerrilla warfare, particularly in the Cholla, Kyongsang and Kangwon provinces, from the Chiri and Taebaek mountain ranges. It was during this time that President Rhee ordered Sung-mo Shin, the minister of defense, to take personal charge in combating the nationwide insurgency rather than being left to individual headquarters in various combat areas. ${ }^{84}$ Consequently, the Chirisan Task Force was created in 1949. With the Task Force taking command of the COIN 
operations both along the border and the Chiri- and Taebek-san area, better results were recorded and guerrilla activities visibly declined in the following months. By March 1950, the insurgency had pretty much died down and ROKA reported that 5,621 guerrillas were either captured or killed with more than 1,000 weapons seized. ${ }^{85}$ The overall strategy was to form an encircling net (powi-mang) around Chiri Mountain as units moved to nearby cities, with the most competent $12^{\text {th }}$ Regiment once again placed as the main strike force. ${ }^{86}$

The initial stages of the suppression campaign did not produce positive results as the insurgent forces (remnants of the rebellious $14^{\text {th }}$ Regiment) held the upper hand; insurgents targeted weakened units located in nearby towns during the night, avoided direct contact whenever possible, and continued with hit-and-run and ambush tactics during this period. ${ }^{87}$ Two interrelated factors can be identified for the initial failures of the constabulary forces. First, the topographical setting, weak communications amongst units, poor quality of maps, and limited supplies all posed major external challenges and constraints for the constabulary. ${ }^{88}$ That is, insurgents were not only much more mobile but were also able to better understand and utilize the external environment. Second, government forces initially played a more passive role as they chased the trails left behind by rebels with information available to them through locals and villagers in the early going. ${ }^{89}$

Nevertheless, COIN performance at the operational and tactical level would show vast improvements through the winter of 1949 and early 1950. First, from a tactical standpoint, the unified command structure allowed the most competent juniorlevel officers to be "hand-picked to fill command and staff positions of the three active task forces and, for once, the ROKA established an effective intelligence net, as well as acquiring adequate transportation and supplies for a sustained winter campaign." 90 The 
selected junior officers displayed tactical adaptability and, as a result, competency, visà-vis the rebel elements. The momentum-shifting battle between Lt. Chi-hoe Kim's insurgent forces and Maj. Paik's $12^{\text {th }}$ Regiment units in Gurye is an example of such initiative and responsiveness displayed by junior-level officers. Completely switching from an offensive plan that had failed in the previous few months, Maj. Paik prepared his regiment to go on the defensive and waited for the enemy to strike first. ${ }^{91}$ The battle on 5 November was the first major blow for the insurgent forces and resulted in an estimated 50 either killed or captured and the remaining elements retreating back to the mountains. ${ }^{92}$ Due to this failure, it is around this time that the insurgents switched from battalion-sized offensives to smaller and more dispersed hit-and-run attacks. ${ }^{93}$ Moreover, the government forces kept building the momentum by integrating civilian measures much more effectively than in previous operations; strict screening procedures were implemented, the civilian defense corps began to player a greater role, and psychological warfare methods such as dropping leaflets were utilized. ${ }^{94}$ During this operation, the ROKA also maintained much improved relationship with KNP. This greatly increased the army's intelligence regarding the whereabouts of the insurgents. ${ }^{95}$ Second, advancements in tactical effectiveness of the government forces under the guidance of the KMAG are another notable factor. Around mid-1949, Gen. William Roberts, the head of the advisory mission, assigned as many advisors as resources would permit all the way to the battalion level to improve the combat effectiveness of the $\mathrm{KC}$, especially in dealing with the COIN operations. ${ }^{96}$ By assigning KMAG advisors more closely, Gen. Roberts could observe the progress of the constabulary forces on the battlefield. ${ }^{97}$ Moreover, such COIN campaigns proved to be valuable for the constabulary/ROKA in terms of on the field combat effectiveness and training. ${ }^{98}$ 
Under such careful US guidance all the way down to the tactical level, improvements were noticed as guerrilla activities started to decline.

\section{Operation RATKILLER}

As the Korean War slowly began reaching a stalemate point, the insurgent forces, comprised of remaining guerrilla elements of previous campaigns along with the fragments of the North Korean forces and leftist sympathizers, continued to mount successful attacks in the rear of the UN forces, effectively forming a second front from within. The remnants of North Korean units left in the southern zone, estimated to be about a force of 40,000, would fight side-by-side along with the communist insurgents. ${ }^{99}$ The remaining communist insurgents in the Chiri Mountains regained their military power under the unified command of Hyun-sang Lee, an experienced guerrilla leader dispatched from the North, under the name of Southern Corps (Nambugun).

During the Chinese People's Volunteer Army's (PVA) Spring Offensive, Lee's Nambugun units bypassed the UN forces and rapidly moved south, occasionally attacking UN and ROK troops from behind and capturing their arms and munitions. While proceeding to the South, Lee's units also assaulted a number of police stations and even temporarily occupied an entire city of Cheongju. When the PVA's offensive was finally stalled by UN forces, Nambugun decided to link up with the remaining insurgents in the Chiri mountain range. Lee claimed a unified command over all the remaining communist guerrilla forces in the southern zone and provided unarmed insurgents with weapons. ${ }^{100}$ Under Lee's leadership, a reorganized guerrilla group of approximately 4,000 insurgents launched large-scale attacks on nearby towns and villages to collect food, and disturb ROKA's supply routes to the frontline. ${ }^{101}$ Even railroads that connect Busan and Daegu, principal parts of the main railroad system in the ROK, could be operated only during the days. ${ }^{102}$ 
In response, the Korean National Assembly voted overwhelmingly in support of military operations to restore law and order within the southern zone. With support from Gen. James Van Fleet, the new Commander of the US Eighth Army and UN-led forces, Task Force Paik was officially created to conduct Operation RATKILLER. ${ }^{103}$ The main objective of this operation was 'to neutralize the guerrillas' longtime Chiri stronghold without further delay., ${ }^{104}$ The overarching COIN strategy was to concentrate ROK forces simultaneously from both the north- and south-side, forming an encirclement around the Chiri mountain area. As Gen. Paik recalls, the instructions from Gen. Van Fleet were as follows: 'One division would land at Yosu and then march north. The other division would travel overland to Taejon and then march south. The two would converge on the Chiri Mountains and attack from all sides at once.' ${ }^{105}$ The task force operated from 30 November 1951 to 15 March 1952.

Compared to security forces of previous COIN operations, the two divisions under the command of Task Force Paik, the Capital and the Eighth Division, were far more experienced by this stage. The Capital Division was included in the task force as it had demonstrated outstanding performance at the frontline. The Division commander, Brigadier General Yo-chan Song had vast experience in COIN operations on Jeju Island and Odea Mountain. In addition, the Eighth Division was familiar with the Chiri Mountain range from previous COIN operations in the area between April and May 1951. ${ }^{106}$ During its earlier COIN operation in the Chiri Mountain area, the division successfully targeted the communist insurgents without massive civilian casualties, unlike previous COIN operations under the command of Brigadier General Yeong-hui Choi. $^{107}$

The formation of Task Force Paik is significant from an operational perspective. The different security branches united under Gen. Paik's headquarters avoided some of 
the cooperation and co-ordination issues from previous operations. Also, the COIN operation was led by Gen. Paik himself as commanding officer of the new task force. Moreover, the leadership of the task force was strongly committed to this COIN operation unlike commanders of previous operations. Leadership frequently took a reconnaissance plane to survey the enemy formation and to ensure that his units operated as planned. During the previous COIN operations, one chronic problem of the ROKA was that some low-level units did not follow the outlined operation plan, avoided engaging enemies, and made inaccurate after-action reports. ${ }^{108}$ Such problems at the operational level were eliminated by the surveillance efforts made of the junior officers. As a result, troops of Task Force Paik took a more aggressive posture. According to records taken by the former insurgents in Chiri Mountain, unlike typical COIN forces who left the mountain by sunset, soldiers under the command of the task force built bunkers and guarded major ridges and hills throughout the operation. ${ }^{109}$ At night, torches were installed in every 100 meters on major ridgelines to block the communists from escaping. As one former insurgent described, 'the whole Chiri Mountain looked like a giant Christmas Tree. ${ }^{, 10}$ This dramatically reduced the overall mobility of the insurgents.

Moreover, Task Force Paik headquarter displayed a high-level of tactical flexibility as it adapted to the operational needs of the campaign. Its commanders assigned missions according to the leadership style of officers and the experience of the actual units. For example, the Capital Division led by Gen. Song would take the mountainous region towards the east; this assignment was made due to the Division's experience in prior COIN operations as well as Gen. Song's volatile yet daring personality. ${ }^{111}$ This flexibility did also stretch down to the lower levels. During the operation Gen. Paik would relieve his highly regarded G-3, Col. Kuk-chin Kong as he 
failed to show tactical adaptability when the situation required. When Col. Yang-soo Yoo, the G-2 of the Task Force, proposed an attack on Mount Tokyu due to latest intelligence on the insurgent whereabouts, Col. Kong opposed it pointing out that it was a deviation from the original plan. As arguments arose, Gen. Paik would side with Col. Yang arguing that it was such flexibility that was a prerequisite to successful COIN operations. ${ }^{112}$ As this example indicates, unlike massive cordon-and-search operations apparent in previous COIN operations, a greater number and precision in intelligence reports and higher level of junior-level officer initiative were one of the key determinants in the successful implementation of Operation RATKILLER.

Such improvements were largely made possible by the unification of the command structure of the government forces. A more centralized, and as a result more cohesive, command also paved the way for the implementation of political and social programs alongside the military mission. ${ }^{113}$ Psychological operations, such as the dropping of leaflets, could now be implemented as part of the COIN strategy. Subsequently, compared to earlier COIN campaigns civilian abuses, by no means eliminated, dropped dramatically. ${ }^{114}$

After operation RATKILLER, the insurgent attacks, both in terms of quantity and intensity, never threatened the internal order in the South before slowly dying down towards the end of the Korean War. With Task Force Paik leading the COIN operations, an estimated 5,009 insurgents were killed and 4,013 either were captured or surrendered. ${ }^{115}$ According to estimates from the former insurgents, approximately 1,200 insurgents survived the operations. ${ }^{116}$ Fundamentally, the task force displayed a higher level of combat effectiveness due to better co-ordination at the tactical level as well as higher level of junior-level officer initiative led to flexible responses at times of need.

\section{Conclusion: lessons learned}


As the accounts of the four cases within the South Korean COIN campaign suggests there were significant differences in the effectiveness of the KC/ROKA units involved in these operations. While the $\mathrm{KC}$ managed to put down the first two uprisings, it was by no means completely successful, as guerrilla warfare spread to other regions of South Korea after the operations. Furthermore, a closer examination of the performance of the security units shows that it was the weakness of the insurgents, rather than the tactical proficiency of the government troops, which was a determining factor in the ROKA's military success. By contrast, the Chiri Mountain campaign and Operation RATKILLER showed a much more proficient ROKA. Not only did the commanders of the operation ensure that the troops under their command would limit civilian abuses, they also showed much greater degrees of operational and tactical proficiency.

An assessment of the campaigns suggests that improvements in performance can be attributed to four major factors. First, the unity of command between the different security forces serves as a critical element for combat effectiveness. Having a branch as the designated lead in the overall operation through an integrated chain of command allowed the government forces to overcome many of the initial problems that it had initially encountered. ${ }^{117}$ The KNP and the KC/ROKA were organizational rivals from the beginning, a rivalry that sometimes even led to actual bloodshed between members of the two organizations. According to the national police, the constabulary was a collection of misfits and left-leaning subversives. The fact that constabulary soldiers were directly involved in starting the Yeo-Soon uprising strengthened their case. In operational terms, however, it is clear that the rivalry between the two and the absence of a clear organizational structure significantly hampered the COIN operations on Jeju Island and the Yeo-Soon campaigns. This problem had been remedied by the time of 
Operation RATKILLER, where the military commander was clearly in charge and the police was subordinated to him.

In addition, the restriction of civilian or political interference often led to the higher performance level of the fighting forces. While the first two campaigns were characterized by a great deal of civilian interference in operational matters, this seemed much less the case during the COIN campaign of the late fall of 1951. According to some, the constant pressure from Seoul to retake Yeo-Soon, for instance, contributed significantly to the constabulary's failure to plan their attacks on Yeo-Soon and other rebel strongholds in sufficient detail. In the end, the focus on retaking Yeo-Soon from the rebels, moreover, also allowed a significant number of them to take refuge in the mountains. In this context, it is also important to note, that the units that performed best during the Jeju and Yeo-Soon campaigns were those in which American field advisers had the greatest amount of influence. ${ }^{118}$ Furthermore, without the political interference of earlier operations Task Force Paik could focus on striking the enemy rather than protecting territory during Operation RATKILLER ${ }^{119}$ Operations did not have to go through unnecessary shifts in policies.

Second, another striking difference between the constabulary of 1948/49 and the ROKA of the fall of 1951 was in the general loyalty of the personnel. When the US advisory mission in Korea started to build the $\mathrm{KC}$, it was largely unaware of the significant ideological and regional cleavages that divided the Korean population in the southern zone. As a result, they recruited widely but without the due selection process required. ${ }^{120}$ This proved disastrous, as many of the members of the constabulary turned out to be less than motivated to fight insurgents given their own opposition to the South Korean government. After the Jeju and Yeo-Soon campaigns, the constabulary was purged of so-called subversive elements. Furthermore, majority of the officers chosen 
for the later operations were largely selected on merit and COIN experience rather than political or personal ties. The Task Force Command also made sure each commanding officer was given assignments based on not just experience but also individual temperament. Consequently, the marked improvement in leadership qualities was another key factor that led to vast improvement in combat effectiveness of the South Korean security forces.

Third, with better coordination and cooperation of the security forces, tactical level mobility was a key characteristic of Operation RATKILLER. A self-assessment of the overall operations pinpoints this aspect as one of the key tactical concepts: '(4) Execution must be rapid. Strong mobile forces operating under rigid control must be utilized. They must be backed up by adequate blocking forces disposed in depth to prevent the escape of small units from dispersed groups.' ${ }^{121}$ The operation focused on striking the enemy with full force in a rapid maneuver of encirclement. Through strict co-ordination, the national police, subordinate to the Task Force Headquarters, would then be responsible of the mop-up operations.

Finally, it seems that structural changes at KMAG also played an important role in improving the operational capabilities of the ROKA units. In the spring of 1951, Gen. Van Fleet recognized the need significantly to increase the size of the advisory mission and to focus its mission on training. Subsequently, the size of the advisory element increased by approximately thirty percent. An integral component for training troops in the Korean case was what was known as the 'counterpart system'. In order to institute and implement the necessary missions in developing an indigenous force, 'the advisory group assigned an American officer to each key position in the Korean national defense establishment, from the Minister of National Defense down to battalion level. ${ }^{122}$ On the insistence of Gen. Roberts and through the counterpart system, US advisors and their 
Korean counterparts shared 'the same office, inspected troops together, attended social functions together, and otherwise shared intimately all daily tasks and problems. ${ }^{123}$ As Walter Hermes points out that the counterpart system was not merely a symbolic gesture nor conducted superficially. On the contrary, the counterpart system was implemented deep down the chain of command all the way to the battalion-level. ${ }^{124}$

In other words, implemented the right way, the counterpart system can certainly attain the intended outcome when developing an indigenous security force. Not only did the system successfully amalgamate US officers and Korean troops, but such a system also allowed American officers to train Korean troops that ensured a certain level of combat effectiveness. ${ }^{125}$ With the start of the Korean War, the system would evolve into what is now known as the Korean Augmentation to US Army (KATUSA). Such innovative means of training contributed to the level of effectiveness of the Korean troops during the later stages of the overall COIN campaigns. In all, together these factors appear to have helped significantly in improving the combat effectiveness of the ROKA, especially as it pertained to small-unit infantry operations.

\section{Acknowledgements}

The authors would like to thank Yoav Gortzak, Alexander Downes, Barnett Koven, Annette Idler, Kevin Petit, Barbara Elias, the participants of the East Asia Politics Workshop at the George Washington University, and the editors of Small Wars and Insurgencies for helpful suggestions and constructive comments on earlier drafts. We would also like to thank Kimberly Peh for providing valuable research assistance.

References:

Appleman, Roy. South to the Naktong, North to the Yalu. Washington, DC: Center of Military History, 1992.

Ahn, Jae-sung. Leehyunsang Pyungjeon [A Critical Biography of Hyun-sang Lee]. Seoul: Shilchunmunhwasa, 2007. 
Ban, Kil-Joo. "Making Counterinsurgency Work: The Effectiveness of the ROK Military's Independent Operational Control in Vietnam and Iraq." Journal of East Asian Affairs 35, no. 1 (2011): 137-174.

Birtle, Andrew. US Army Counterinsurgency and Contingency Operations Doctrine 1942-1976. Washington, DC: Center of Military History, 2006.

Blair Jr., Clay. The Forgotten War: America in Korea, 1950-1953. New York: Times Books, 1987.

Blumenson, Martin. “KATUSA.” Military Review 52 (1957): 51-56.

Braim, Paul. The Will to Win: The Life of General James A. Van Fleet. Annapolis: Naval Institute Press, 2011.

Byman, Daniel. "Friends Like These: Counterinsurgency and the War on Terrorism." International Security 31, no. 2 (2006): 79-115.

Clancy, James, and Chuck Crossett. "Measuring Effectiveness in Irregular Warfare." Parameters 37, no. 2 (2007): 88-100.

Commission for Military History. Daebijeonggyusa: 1945-1960 [History of CounterIrregular War: 1945-1960]. Seoul: Commission for Military History, 1988.

Cumings, Bruce. The Origins of the Korean War, Vol. II: The Roaring of the Cataract 1947-1950. Princeton: Princeton University Press, 1990. Korea's Place in the Sun: A Modern History. New York: W. W. Norton, 1997.

Daddis, G. No Sure Victory: Measuring U.S. Army Effectiveness and Progress in the Vietnam War. New York: Oxford University Press, 2011.

David, G. J. "The Interagency Abroad: The New Paradigm Progress.” Military Review XC, no. 1 (Jan-Feb 2010): 58-62.

Deane, Hugh. The Korean War 1945-1953. San Francisco: China Books \& Periodicals, 1999.

G-2 Historical Section, USAFIK. History of the United States Army Forces in Korea, Part III. Seoul: 1948. Accessed on June 11, 2015. http://db.history.go.kr/id/husa_003_0040_0010_0150

Gibby, Bryan. The Will to Win: American Military Advisors in Korea, 1946-1953. Tuscaloosa: University of Alabama Press, 2012.

George, Alexander, and Andrew Bennett. Case Studies and Theory Development in the Social Sciences. Cambridge: MIT Press, 2005. 
Gortzak, Yoav. "Using Indigenous Forces in Counterinsurgency Operations: The French in Algeria, 1954-1962." Journal of Strategic Studies 32, no. 2 (2009): 307-333.

Hajjar, Remi. "What Lessons Did we Learn (or Re-Learn) About Military Advising After 9/11?” Military Review (Nov-Dec 2014): 63-75.

Hausman, James H. Hangook Daetongyrungul Uhmjik-in Meegun Daewhee, Il-hwa Jung ed. [The American Army Captain Who Influenced Korean Presidents]. Seoul: Hankuk Moonwon, 1995.

Hermes, Walter G. Survey of the Development of the Role of the US Army Military Advisor. Washington, DC: Office of the Chief of Military History, 1965.

Huh, Nam-Sung. "The Quest for a Bulwark of Anti-Communism: The Formation of the Republic of Korea Army Officer Corps and Its Political Socialization, 19451050." PhD diss., Ohio State University, 1987.

Institute for Military History. Geongunsa [History of the Establishment of the ROK Army]. Seoul, 2002.

Jeong, Gwanho. Jeonnam Yugyeogtujaengsa [History of Guerrilla Resistance in South Jeolla Province]. Seoul: Seonin, 2008.

Jung, Choongjae, Shilrok Jung Soon-duk 1 [The True Record of Jung Soon-duk 1]. Seoul: Deajaehak, 1989.

Kang, Chan-gi, interviewed by Sang-geun Lee, August 29, 2009, interview 5, transcript, 2009 Oral History Projects, National Institute of Korean History, Gwacheon, Gyeonggi-do, Republic of Korea.

Kim, Deukjung. "The Yeo-Soon Rebellion and James Hausman." Paper Presented at the Seminar on the $53^{\text {rd }}$ Anniversary of the Yeo-Soon Incident, Yeosu, Republic of Korea, October 19, 2001. Ppalgaengiui Tansaeng [The Birth of Commies]. Seoul: Seonin, 2009.

Kim, Nam Sik. "The Characteristics of Communist Partisan Movement in South Korea between 1948 and 1950.” In Haebang Jeonhusaui Insik 4 [Understanding History of Korea Before and After its Independence 4], edited by Jung Hae-gu et al., 207-243. Seoul: Hangilsa, 1989.

KMAG $8202^{\text {nd }}$ Army Unit, AG Section, Military Historian's file, RG 554, National Archives, Washington, DC. 
Koh, Bong-sik, interviewed by Sung-yun Cho and Hye-kyung Hyun, April 29, 2004, interview 1, transcript, 2004. Oral History Projects, National Institute of Korean History. Gwacheon, Gyeonggi-do, Republic of Korea.

Lee, Tae, Nambugun [Southern Corps]. Seoul: Yeolim, 1988.

Lee, Young-woo. "The United States and the Formation of the Republic of Korea Army 1945-1950.” PhD diss., Duke University, 1984.

Merrill, John. “The Cheju-do Rebellion.” Journal of Korean Studies 2 (1980): 139-197. . Korea: The Peninsular Origins of the War. Newark: University of Delaware Press, 1989.

Millett, Allan R. "Captain James H. Hausman and the Formation of the Korean Army, 1945-1950.” Armed Forces and Society 23, no. 4 (Sum. 1997): 503-539.

Millett, Allan R. The War for Korea, 1945-1950: A House Burning. Lawrence, KS: University Press of Kansas, 2006.

Millett, Allan, Williamson Murray, and Kenneth Watman. "The Efficiency of Military Organizations." In Military Effectiveness: The First World War, Vol. I, edited by Allan Millett and Williamson Murray, 1-30. Boston: Unwin Hyman, 1988.

Noh, Young-ki. "YoSun Incident and Change of the Korean Army." Chunnam Sahak [Chunnam History Journal] 22 (2004): 253-277.

Oh, Bonnie. "Introduction: The Setting." In Korea Under the Military Government, 1945-1948, edited by Bonnie Oh, 1-11. Westport: Praeger, 2002.

Paik, Sun-Yup. Shilrok Chiri-san [The True Record of Chiri Mountain]. Seoul: Koryeowon, 1992.

From Pusan to Panmunjom. Washington, DC: Brassey's, 1992.

Paik, Sun-Yup, interviewed by Jung-ae Ahn, August 18, 2004, interview 3 (1), transcript, 2004 Oral History Projects, National Institute of Korean History, Gwacheon, Gyeonggi-do, Republic of Korea.

Pan-National Committee for Truth Concerning Civilian Massacres. Hangukjeonjaengjeonhu Minganinhaksal Siltaebogoseo [Fact-finding Report on Civilian Massacre Before and After the Korean War]. Paju: Hanul, 2005.

Park, Il-Song. "The Dragon from the Stream: The ROK Army in Transition and the Korean War, 1950-1953.” PhD diss., Ohio State University, 2002.

Park, Soul. "The Unnecessary Uprising: Jeju Island Rebellion and South Korean Counterinsurgency Experience 1947-1948.” Small Wars and Insurgencies 21, no. 2 (Jun. 2010): 359-381. 
Ramsey III, Robert D. Advising Indigenous Forces: American Advisors in Korea, Vietnam, and El Salvador. Fort Leavenworth, KS: Combat Studies Institute Press, 2006.

Records of the Army Staff, Office of the Chief of Military History, KMAG Background Files, RG 319, National Archives, Washington, DC.

Republic of Korea Army Headquarters, Yookgoon Baljeonsa I [History of the ROK Army's Development, Vol. I] (Seoul, 1969).

Reardon, Mark J. "Chasing a Chameleon: The US Army Counterinsurgency Experience in Korea, 1945-1952." In The U.S. Army and Irregular Warfare, 1775-2007, edited by Richard G. Davis, 213-228. Washington, DC: Center of Military History, 2008.

Sarkesian, Sam. (ed.). Combat Effectiveness: Cohesion, Stress, and the Volunteer Army. Beverly Hills: Sage, 1980.

Sawyer, Robert K. Military Advisors in Korea: KMAG in Peace and War. Washington, DC: Center of Military History, 1988.

Skaggs, David, and Richard Weinert. American Military Assistance to the Republic of Korea Army, 1951-1965. Unpublished manuscript.

Souleimanov, Emil Aslan, and Huseyn Aliyev. "Evaluating the Efficacy of Indigenous Forces in Counterinsurgency: Lessons from Chechnya and Dagestan.” Small Wars and Insurgencies 27, no. 3 (2016): 392-416.

Stoker, Donald. (ed.). Military Advising and Assistance: From Mercenaries to Privatization, 1815-2007. London: Routledge, 2008.

The National Committee for Investigation of the Truth about the Jeju April 3 Incident. Final Report of Investigation of Jeju April 3 Incident. Seoul: Sunin-sa, 2003. Yeosu Community Research Institute. Written Investigation of the Realities of the Yeosu-Soonchun Incident, Vol. 1. Yeosu: Yeosu Community Research Institute, 1998. . Dasisseuneun Yeosunsageonbogoseo [Revised Reports on the YeoSoon Incident]. Paju: Korean Studies Information, 2012.

Yoo, Chae-hung. Gyeokdongui Sewol [In Time of Turbulence]. Seoul: Euljimunhwasa 1994. 
${ }^{1}$ The proto-Communist guerrillas, which formed as a result of the Autumn Uprising of 1946, later attracted followers and developed into full insurgent movements when the UN decided to establish a separate government in the southern zone. See, Nam Sik Kim, 'The Characteristics of Communist Partisan Movement in South Korea between 1948 and 1950,' in Haebang Jeonhusaui Insik 4 [Understanding History of Korea Before and After its Independence 4] (Seoul: Hangilsa, 1989), 209; and Commission for Military History, Daebijeonggyusa: 1945-1960 [History of Counter-Irregular War in Korea: 1945-1960] (Seoul: Commission for Military History, 1988), 21.

${ }^{2}$ The communist insurgents did not pose much of a threat after 1954. The insurgency was completely eradicated by 1963, when 'the last Partisan' Soon-duk Jung was captured by the Korean National Police forces. Choongjae Jung, Shilrok Jung Soon-duk 1 [The True Record of Jung Soon-duk 1] (Seoul: Deajaehak, 1989).

${ }^{3}$ For more on combat effectiveness, see Sam Sarkesian (eds.), Combat Effectiveness: Cohesion, Stress, and the Volunteer Army (Beverly Hills: Sage, 1980); and Allan Millett, Williamson Murray and Kenneth Watman, "The Efficiency of Military Organizations," in Allan Millett and Williamson Murray (eds.), Military Effectiveness: The First World War, Vol. I (Boston: Unwin Hyman, 1988), 130.

${ }^{4}$ The training of the ROKA fell under the responsibility of the Provincial Military Advisory Group (PMAG) and then the United States Military Advisory Group to the Republic of Korea (KMAG) in 1949. Undermanned for the most part, especially after the departure of the US from the Korean peninsula in 1949, the US officers played an advisory role in the development of the ROK forces.

${ }^{5}$ For instance, see Gregory Daddis, No Sure Victory: Measuring U.S. Army Effectiveness and Progress in the Vietnam War (New York: Oxford University Press, 2011); James Clancy and Chuck Crossett, 'Measuring Effectiveness in Irregular Warfare,' Parameters 37, no 2 (2007): 88-100; and Kil-Joo Ban, “Making Counterinsurgency Work: The Effectiveness of the ROK Military’s Independent Operational Control in Vietnam and Iraq," Journal of East Asian Affairs 35, no. 1 (Spring/Summer 2011): 137-174. 
${ }^{6}$ Robert Ramsey, Advising Indigenous Forces: American Advisors in Korea, Vietnam, and El Salvador

(Fort Leavenworth: Combat Studies Institute Press, 2006), 1. For more on advisory missions, see Stoker, Donald (ed.), Military Advising and Assistance: From Mercenaries to Privatization, 1815 2007 (London: Routledge, 2008).

${ }^{7}$ For some recent work, see Daniel Byman, 'Friends Like These: Counterinsurgency and the War on Terrorism,' International Security 31, no. 2 (2006): 79-115; Yoav Gortzak, 'Using Indigenous Forces in Counterinsurgency Operations: The French in Algeria, 1954-1962,' Journal of Strategic Studies 32, no. 2 (2009): 307-333; and Emil Souleimanov and Huseyn Aliyev, 'Evaluating the Efficacy of Indigenous Forces in Counterinsurgency: Lessons from Chechnya and Dagestan,' Small Wars and Insurgencies 27, no. 3 (2016): 392-416.

${ }^{8}$ Alexander George and Andrew Bennett, Case Studies and Theory Development in the Social Sciences (Cambridge: MIT Press, 2005), 21-22 and chapter 7.

${ }^{9}$ For a summary of the hectic period, see Bonnie Oh, 'Introduction: The Setting,' in Bonnie Oh (ed.), Korea Under the Military Government, 1945-1948 (Westport: Praeger, 2002), 1-11.

${ }^{10}$ Young-woo Lee, 'The United States and the Formation of the Republic of Korea Army 1945-1950' (PhD Dissertation, Duke University, 1984), 5. (emphasis added) Also, see Walter Hermes, Survey of the Development of the Role of the U.S. Military Advisor (Washington, DC: Office of the Chief of Military History, 1965), 10-11.

11 'In principle, the Korean Constabulary remained a reserve force for the police during 1946 and 1947.' Robert Sawyer, Military Advisors in Korea: KMAG in Peace and War (Washington, DC: Center of Military History, 1988), 13, 26. Also, see Nam-Sung Huh, 'The Quest for a Bulwark of AntiCommunism: The Formation of the Republic of Korea Army Officer Corps and Its Political Socialization, 1945-1950’' $\mathrm{PhD}$ Dissertation, Ohio State University, 1987), 124.

${ }^{12}$ Huh, 'The Quest for a Bulwark,' 120-121. For more on the BAMBOO Plan, see Sawyer, Military Advisors in Korea, 11-14.

${ }^{13}$ Lee, 'The United States and the Formation of the Republic of Korea Army,' 161-162.

${ }^{14}$ Allan Millett, The War for Korea, 1945-1950: A House Burning (Lawrence: University Press of Kansas, 2006), 164. Also, see Sawyer, Military Advisors in Korea, 34-35. 
${ }^{15}$ Sawyer, Military Advisors in Korea, 45. Also, see David Skaggs and Richard Weinert, American Military Assistance to the Republic of Korea Army, 1951-1965 (unpublished manuscript), 9.

${ }^{16}$ Robert Gibby, The Will to Win: American Military Advisors in Korea, 1946-1953 (Tuscaloosa: University of Alabama Press, 2012), 71-73.

${ }^{17}$ Hermes, Survey of the Development of the Role of the U.S. Military Advisor, 50, 82; Lee, 'The United States and the Formation of the Republic of Korea Army,' 82, 100; and Sawyer, Military Advisors in Korea, 62-65.

${ }^{18}$ Andrew Birtle, U.S. Army Counterinsurgency and Contingency Operations Doctrine 1942-1976 (Washington, DC: Center of Military History, 2006), 88, 91; Hermes, Survey of the Development of the Role of the U.S. Military Advisor, 49-50; Huh, 'The Quest for a Bulwark,' 125, 128, 165; Lee, 'The United States and the Formation of the Republic of Korea Army,' 110-111; and Il-Song Park, 'The Dragon from the Stream: The ROK Army in Transition and the Korean War, 1950-1953' (PhD Dissertation, Ohio State University, 2002), 27.

${ }^{19}$ James Hausman, Hangook Daetongyrungul Uhmjik-in Meegun Daewhee, Il-hwa Jung ed. [The American Army Captain Who Influenced Korean Presidents] (Seoul: Hankuk Moonwon, 1995), 136137; and Sawyer, Military Advisors in Korea, 26-32.

${ }^{20}$ Such tensions were especially serious between the islanders and police officers from the mainland Korea. Starting from the March 1 incident, the KNP increased the number of its personnel by dispatching officers from the main land. In July of 1948, the three fourth of the officers in Jeju were mainlanders. Bong-sik Koh, interviewed by Sung-yun Cho and Hye-kyung Hyun, April 29, 2004, interview 1, transcript, 2004 Oral History Projects, National Institute of Korean History, Gwacheon, Gyeonggi-do, ROK, 59; The National Committee for the Investigation of the Truth about the Jeju April 3 Incident, Final Report of Investigation of Jeju April 3 Incident, (Seoul: Sunin-sa, 2003), 87.

${ }^{21}$ Soul Park, 'The Unnecessary Uprising: Jeju Island Rebellion and South Korean Counterinsurgency Experience 1947-1948,' Small Wars and Insurgencies 21, no. 2 (2010): 359-381.

22 The National Committee, 188-189; and John Merrill, 'The Cheju-do Rebellion,' Journal of Korean Studies 2 (1980): 168.

23 The National Committee, Final Report of Investigation, 217-218. 
${ }^{24}$ Merrill, 'The Cheju-do Rebellion,' 175; and Hugh Deane, The Korean War 1945-1953 (San Francisco:

China Books \& Periodicals, 1999), 58.

25 The National Committee, Final Report of Investigation, 219-221.

${ }^{26}$ Ibid., 293-296.

27 John Merrill, Korea: The Peninsular Origins of the War (Newark: University of Delaware Press, 1989), 123.

${ }^{28}$ Birtle, US Army Counterinsurgency, 97.

${ }^{29}$ Merrill, Korea, 132; and Merrill, “The Cheju-do Rebellion,” 189.

${ }^{30}$ Merrill, 'The Cheju-do Rebellion,' 189; and The National Committee, Final Report of Investigation, 320.

${ }^{31}$ Merrill, 'The Cheju-do Rebellion,' 189-190.

32 The National Committee, Final Report of Investigation, 323.

${ }^{33}$ Merrill, Korea, 124-125.

34 The National Committee, Final Report of Investigation, 327.

${ }^{35}$ G-2 Historical Section, USAFIK, History of the United States Army Forces in Korea, Part III (Seoul: 1948), Chapter IV. http://db.history.go.kr/id/husa_003_0040_0010_0150; Chan-gi Kang, interviewed by Sang-geun Lee, August 29, 2009, interview 5, transcript, 2009 Oral History Projects, National Institute of Korean History, Gwacheon, Gyeonggi-do, ROK, 102

${ }^{36}$ The National Committee, Final Report of Investigation, 189-190.

${ }^{37} \mathrm{KNP}$ force is estimated to have had a force of roughly 2,000 at the height of violence in 1948. Merrill, 'The Cheju-do Rebellion,' 168; and The National Committee, Final Report of Investigation, 221-222.

${ }^{38}$ According to a testimony from the former civil activity personnel of the $\mathrm{KC}$ during the operation, one of the main reasons why the islanders joined the $\mathrm{KC}$ was to save their lives from abuses from the KNP. Koh, interview 1, 58.

${ }^{39}$ Ibid., 168; and Deane, The Korean War, 56.

${ }^{40}$ The National Committee, Final Report of Investigation, 191.

${ }^{41}$ Allan Millett, 'Captain James H. Hausman and the Formation of the Korean Army, 1945-1950,' Armed Forces and Society 23, no. 3 (1997): 522.

42 The National Committee, Final Report of Investigation, 216. 
${ }^{43}$ Quote from Merrill, 'The Cheju-do Rebellion,' 187.

${ }^{44}$ Chae-hung Yoo, Gyeokdongui Sewol [In The Time of Turbulence] (Seoul: Euljimunhwasa 1994), 95.

${ }^{45}$ Bruce Cumings, The Origins of the Korean War, Vol. II (Berkeley: University of California Press, 1967), 269.

${ }^{46}$ The KC changed its name to the ROKA in September 1948, shortly after formal establishment of the Republic of Korea in August 1949. As for the organization of the ROKA, brigade was the largest tactical unit of the Army up until May 1949, when the ROKA activated its first divisions by reorganizing the existing brigades. For more, see Institute for Military History, Geongunsa [History of the Establishment of the ROK Army] (Seoul, 2002), 162-163; and Park, 'The Dragon from the Stream,' 38.

47 'The Truth About the Yosu Incident,' Captain R. K. Sawyer files, Records of the Army Staff, Office of the Chief of Military History, KMAG Background Files, RG 319, 1. Also, see Merrill, Korea, 99; and Young-ki Noh, 'YoSun Incident and Change of the Korean Army,' Chunnam Sahak [Chunnam History Journal] 22 (2004), 257.

${ }^{48}$ The regiment possessed an estimated surplus of 3,000 weapons. Merrill, Korea, 102; and ROK Army Headquarters, Yookgoon Baljeonsa I [History of the ROK Army's Development, Vol. I] (Seoul, 1969), 249.

${ }^{49}$ Rebel forces were estimated to be between 1,000 and 2,000. Noh, 'YoSun Incident,' 258; Merrill, Korea, 98, 101; Sun-yup Paik, Shilrok Chiri-san [The True Record of Chiri Mountain], (Seoul: Koryeo-won, 1992), 152-156; and Gibby, The Will to Win, 54.

${ }^{50}$ Merrill, Korea, pp. 103-104; ROK Army, Yookgoon Baljeonsa I, 249; "The Truth About the Yosu Incident," 2; and US Army, XXIV Corps, G-3, 'History of the Rebellion of the $14^{\text {th }}$ Regiment and the $6^{\text {th }}$ Regiment of the Korean Constabulary,' in Yeosu Community Research Institute, Written Investigation of the Realities of the Yeosu-Soonchun Incident, Vol. 2 (Yeosu: Yeosu Community Research Institute, 1999), 115.

${ }^{51}$ According to the Army official publication, during the one week period of the uprising, the insurgents killed 1,200 people, with an additional 1,150 attaining serious injuries and roughly 9,800 becoming refugees through the process. Furthermore, around 400 people were affected in the city of Soonchun. 
ROK Army, Yookgoon Baljeonsa I, 249. Also see, Paik, Shilrok Chiri-san, 167-171; and Millett,

‘Captain James H. Hausman,' 523.

${ }^{52}$ Gibby, The Will to Win, 54-55; US Army, 'History of the Rebellion,' 115; Merrill, Korea, 105; and Paik, Shilrok Chiri-san, 168.

${ }^{53}$ ROK Army Headquarters, Yookgoon Baljeonsa I, 250; and US Army, XXIV Corps, G-3, 'History of the Rebellion,' 116.

${ }^{54}$ Paik, Shilrok Chiri-san, 164-165; Millett, The War for Korea, 168; 'The Truth About the Yosu Incident,' 3; US Army, 'History of the Rebellion,' 117; and Gibby, A Will to Win, 55.

${ }^{55}$ ROK Army, Yookgoon Baljeonsa I, 251-252.

${ }^{56}$ Merrill, Korea, 108; US Army, 'History of the Rebellion,' 119; and Millett, 'Captain James H. Hausman,' 524.

${ }^{57}$ Cumings, The Origins of the Korean War, 287-289.

${ }^{58}$ US Army, 'History of the Rebellion,' 119; Cumings, The Origins of the Korean War, 286; and Paik, Shilrok Chiri-san, 172.

${ }^{59}$ Merrill, Korea, 108-109, and Paik, Shilrok Chiri-san, 180-181.

${ }^{60}$ Merrill, Korea, 109.

${ }^{61}$ Merrill, Korea, 110; and Paik, Shilrok Chiri-san, 185-186.

${ }^{62}$ Merrill, Korea, 111; and US Army, 'History of the Rebellion,' 124.

${ }^{63}$ Paik, Shilrok Chiri-san, 186-187.

${ }^{64}$ According to Allan Millett, Col. Hurley E. Fuller, one of the American advisors to assisting the ROKA, intentionally distracted Gen. Song during the first ten days of the COIN operations. Millett, 'Captain James H. Hausman,' 524.

${ }^{65}$ Deukjung Kim, Ppalgaengiui Tansaeng [The Birth of Commies] (Seoul: Seonin, 2009), 237-238.

${ }^{66}$ Institute for Military History, Geongunsa, 39-44.

${ }^{67}$ Deukjung Kim, 'The Yeo-Soon Rebellion and James Hausman' (Paper presented at the Seminar on the $53^{\text {rd }}$ Anniversary of the Yeo-Soon Incident, Yeosu, Republic of Korea, October 19, 2001$), 5$.

${ }^{68}$ Ibid., 244.

${ }^{69}$ Yeosu Community Research Institute, Dasisseuneun Yeosunsageonbogoseo [Revised Reports on the Yeo-Soon Incident] (Paju: Korean Studies Information, 2012), 80. 
${ }^{70}$ Although no hierarchical command between the ROKA and KNP units existed, there was a clear division of labor between the two. While most combat operations against rebels were conducted by the ROKA, the KNP forces focused more on sorting out remaining rebels in recovered areas. Kim, Ppalgaengiui Tansaeng, 308-309.

${ }^{71}$ Millett, The War for Korea, 1945-1950, 169.

${ }^{72}$ Gibby, The Will to Win, 65.

${ }^{73}$ Ibid., 57.

${ }^{74}$ Millett, 'Captain James H. Hausman,' 525; US Army, 'History of the Rebellion,' 121; Merrill, Korea, 109; and Gibby, The Will to Win, 56-57.

${ }^{75}$ Merrill, Korea, 109; and Paik, Shilrok Chiri-san, 174-175, 184.

${ }^{76}$ All this was compounded by continuous interference in operational matters by the civilian leadership in Seoul. See Millett, 'Captain James H. Hausman,' 525; Gibby, The Will to Win, 56-57; and Merrill, Korea, 110-111.

${ }^{77}$ Millett, 'Captain James H. Hausman,' 527; Merrill, Korea, 115; and Gibby, The Will to Win, 53.

${ }^{78}$ Merrill, Korea, 116.

${ }^{79}$ Cumings, The Origins of the Korean War, 286.

${ }^{80}$ The officially identified civilian death count is at 884 . For more, see Yeosu Community Research Institute, Written Investigation of the Realities of the Yeosu-Soonchun Incident, Vol. 1 (Yeosu: Yeosu Community Research Institute, 1998), 88 (table); Merrill, Korea, 112-114; and Deane, The Korean War, 60 .

${ }^{81}$ Bruce Cumings, Korea's Place in the Sun: A Modern History (New York: W.W. Norton, 1997), 243.

${ }^{82}$ US Army, 'History of the Rebellion,' 124; Sawyer, Military Advisors in Korea, 74; Gibby, The Will to Win, 76; and Millett 'Captain James H. Hausman,' 529.

${ }^{83}$ Gibby, The Will to Win, 76-77.

${ }^{84}$ Ibid., 77-79.

${ }^{85}$ Ibid., 78-80.

${ }^{86}$ Paik, Shilrok Chiri-san, 220-221.

${ }^{87}$ Merrill, Korea, 120.

${ }^{88}$ Ibid., 119-120. 
${ }^{89}$ For some of the early struggles, see Paik, Shilrok Chiri-san, 223-229.

${ }^{90}$ Gibby, The Will to Win, 89.

${ }^{91}$ Paik, Shilrok Chiri-san,231-232.

${ }^{92}$ Merrill, Korea, 120.

${ }^{93}$ Ibid., 121.

${ }^{94}$ Cumings, Korea's Place in the Sun, 244-245; and Merrill, Korea, 121.

${ }^{95}$ Sun-Yup Paik, interviewed by Jung-ae Ahn, August 18, 2004, interview 3 (1), transcript, 2004 Oral History Projects, National Institute of Korean History, Gwacheon, Gyeonggi-do, ROK, 17.

${ }^{96}$ Sawyer, Military Advisors in Korea, 32, 44-45.

${ }^{97}$ Gibby, The Will to Win, 76; and Cumings, Korea's Place in the Sun, 246.

${ }^{98}$ Sawyer, Military Advisors in Korea, 25.

${ }^{99}$ Hugh Deane, according to an unidentified official source, argues that the guerrilla forces throughout the South were estimated to be around, 40,000. Deane, The Korean War, 99. Also, see Sun-yup Paik, From Pusan to Panmunjom (Washington, DC: Brassey's, 1992), 182-183; and Birtle, U.S. Army Counterinsurgency, 100.

100 Tae Lee, Nambugun [Southern Corps] (Seoul: Yeolim, 1988), 211.

${ }^{101}$ Roy Appleman, South to the Naktong, North to the Yalu (Washington: Center of Military History, 1992), 722. For more on the Korea War, see Clay Blair Jr., The Forgotten War: America in Korea, 1950-1953 (New York: Times Books, 1987).

102 Paik, interview 3 (1), 23.

${ }^{103}$ Gibby, The Will to Win, 213.

104 Paik, From Pusan to Panmunjom, 182.

${ }^{105}$ Ibid., 180.

${ }^{106}$ Paik, Shilrok Chiri-san, 17.

${ }^{107}$ Ibid., 324-325.

108 Ibid., 36.

${ }^{109}$ Gwanho Jeong, Jeonnam Yugyeogtujaengsa [History of Guerrilla Resistance in South Jeolla Province] (Seoul: Seonin, 2008), 154. 
110 Jae-sung Ahn, Leehyunsang Pyungjeon [A Critical Biography of Hyun-sang Lee] (Seoul:

Shilchunmunhwasa, 2007), 478

${ }^{111}$ Paik, Shilrok Chiri-san, 48.

112 Paik, From Pusan to Panmunjom, 189-190.

${ }^{113}$ Ibid., 185; and Mark Reardon, 'Chasing a Chameleon: The US Army Counterinsurgency Experience in Korea, 1945-1952,' in Richard Davis (ed.), The US Army and Irregular Warfare (Washington, DC: Center of Military History, 2008), 226.

${ }^{114}$ Pan-National Committee for Truth Concerning Civilian Massacres, Hangukjeonjaengjeonhu Minganinhaksal Siltaebogoseo [Fact-finding Report on Civilian Massacre Before and After the Korean War] (Paju: Hanul, 2005), 11.

${ }^{115}$ Committee for Military History, Counter-Irregular War, 217.

${ }^{116}$ Jeong, Jeonnam Yugyeogtujaengsa, 160.

117 This point is echoed in a more recent piece on interagency process: “a nation's contribution in a conflict zone should be, at least in principle, as simple and cohesive as possible.” Maj. G. J. David, 'The Interagency Abroad: The New Paradigm Progress,' Military Review XC, no. 1 (JanuaryFebruary 2010): 60 .

118 These advisers, however, did not have actual control over the units to whom they were assigned. They influenced their Korean counterparts during training and operations via persuasion and suggestion. Sawyer, Military advisors in Korea, 60.

${ }^{119}$ KMAG $8202^{\text {nd }}$ Army Unit, AG Section, Military Historian's file (16 November 1951-8 February 1952), RG 554.

${ }^{120}$ Gibby, The Will to Win, 48.

${ }^{121}$ KMAG $8202^{\text {nd }}$ Army Unit, Military Historian’s file. (Lessons learned section)

${ }^{122}$ Lee, 'The United States and the Formation of the Republic of Korea Army,' 162; and Sawyer, Military Advisors in Korea, 58-61.

123 Ibid.

${ }^{124}$ Hermes, Survey of the Development of the Role of the US Army Military Advisor, 49-50.

${ }^{125}$ Gibby, The Will to Win, 58. For more on KATUSA, see Paul Braim, The Will to Win: The Life of General James A. Van Fleet (Annapolis, MD: Naval Institute Press, 2011), 277-278; and Martin 
Blumenson, 'KATUSA,' Military Review 52 (1957): 51-56. For views echoing the importance of the counterpart system to the more recent campaigns, see Lt. Col. Remi Hajjar, "What Lessons did We Learn (or Re-Learn) About Military Advising After 9/11?” Military Review (November-December 2014): 65-66. 